\title{
Knowledge and Attitudes among Tanta University Students Regarding to Genetic
}

\section{Disorders and Genetic Counseling}

\author{
Entesar Abo-Elghit El-Hosany ${ }^{1}$, Samia E. Khaton ${ }^{2}$ \\ ${ }^{1,2}$ Assistant professors of Community health Nursing, Faculty of Nursing, Tanta University
}

\begin{abstract}
Background: Advancements in genomic sciences turned the focus of health care from the diagnosis and treatment of genetic diseases to genetic risk identification, genetic counseling and protective actions. This study aimed to assess perception of genetic disorders and genetic counseling among Tanta University students. Design and Setting a descriptive crosssectional study design. The study was conducted at four Faculties (Faculty of Engineering, Arts, Nursing and Pharmacy) that were selected randomly from medical and non-medical fields in Tanta University. Subjects: A sample of $13.8 \%$ of students in the $4^{\text {th }}$ academic year were selected (1005 students) by stratified random sample technique. Tool (1): Structured interview schedule developed by the researchers to assess students' knowledge regarding genetic disorders and genetic counseling. Tool (2): Attitude of university students towards genetic disorders and genetic counseling. Results: $77.6 \%$ of students had poor level of knowledge, while $87.2 \%$ of them showed positive attitude toward genetic disorders and genetic counseling. Three quarters (75\%) of students hadn't any information source about genetic counseling. Conclusion: The majority of students had poor knowledge, most of them had positive attitude, and there was a marked lack in the different information sources of genetic disorders and genetic counseling which constituted a major cause behind the deficiency in knowledge. Recommendation: Integration of modern genetics and genomics into basic and advanced educational programs of Egypt, genetic carrier testing of prevalent genetic diseases in Egypt should made available for university students with accepted costs and adequate coverage.
\end{abstract}

Key words: - Genetic Disorders, Genetic Counseling, Awareness, University students 


\section{Introduction}

A genetic disorder is an illness caused when a something goes wrong in the genes or chromosomes. It can be a result of small mutation in one single gene, adding or subtracting of an entire chromosome, or the addition or subtraction of asset of chromosomes. Other genetic disorders are multifactorial, in which many genes interact, and environmental influences are also elements in disease development ${ }^{(1)}$.

One out of every ten adults have a genetic defect ${ }^{(2)}$. Genetic disorders affect about $5 \%$ of world's population with diseases ${ }^{(3)}$. Thirty percent (30\%) of pediatric admission and $10 \%$ of adult admission in developed countries is due to genetic causes ${ }^{(4)}$. The disease may be rare but the total number of people with genetic diseases is substantial. There are approximately 30 million people are affected with rare diseases in the USA ${ }^{(1)}$.

Genetic disorders are more prevalent among Arab population. Coronary arteries disease, arteriosclerosis, diabetes mellitus, hypertension, and obesity are common genetic disorders in Arab countries. Many of these disorders have assumed its epidemic proportion. Other diseases for example: Down Syndrome, Breast Cancer, Tetralogy of Fallot, Familial Mediterranean Fever, Deafness, Noonan Syndrome and Ankylosing Spondylitis, Thalassemia, Sickle Cell Disease, and
Glucose-6-Phosphate

Dehydrogenase

Deficiency, are also highly prevalent diseases and occur at annual incidence of (> 100 cases per 100000 live births) among Arab population ${ }^{(5)}$.

The distribution of genetic disorders in the Arab world according to disease taxonomies indicates that over one-third of genetic disorders in Arab individuals result from congenital malformations and chromosomal abnormalities (more than $35 \%)^{(6)}$.

In Egypt, genetic diseases remain a major cause of morbidity, mortality and handicaps. There are a high prevalence of genetic disorders and congenital mal formations among Egyptians, with frequencies comparable to other Arab populations. Central nervous system (CNS) anomalies are the most prevalent congenital malformations as confirmed by numerous epidemiological studies ${ }^{(7,8)}$. High rate of consanguinity, large family size, and low availability of public health measures directed at the care and prevention of these disorders are of the important predisposing factors that are founded in Arab populations ${ }^{(5)}$.

Genetic disorders are chronic in nature, require lifelong management with no definitive cure and continue to negatively affect the health care system through increasing rates of neonatal deaths, morbidity and mortality in children as well 
as in adults. These constitute a significant economic and psychosocial burden on patients, families, health care systems and the whole society ${ }^{(5)}$. In recent years, health economists have made significant advances in calculating generally accepted 'cost of illness' estimates for many common genetic conditions. Thus, it is estimated that billions of United States Dollars are spent annually to manage just a few of the most common genetic diseases in the Arab world. These makes it essential to improve the preventive strategies for controlling the prevalence of genetic diseases ${ }^{(9)}$.

Genetic screening programs are effective in decreasing the impact of genetic disorders on families and societies and lead to early treatment and improvements in outcome and prognosis ${ }^{(5)}$. The main types of genetic screening include carrier screening, prenatal diagnosis, and newborn screening. Genetic carrier screening identifies asymptomatic carriers of common recessive conditions in the community, it allows health professional to intervene early to prevent disease occurrence in the offspring of detected carriers (10). Prenatal diagnosis and newborn screening programs early detect genetic conditions and enable timely medical or surgical interventions to inhibit deleterious implication of a genetic condition on health ${ }^{(11,12)}$.
Family screening is another preventive approach and it seems to be more helpful in regions that have high level of consanguinity as in Egypt and many other Arab countries. Family screening is mainly effective for single gene disorders that represents more than half $(56 \%)$ of the genetic disorders described among Arabs ${ }^{(13,5)}$. Family history, pedigree analysis and genetic counseling interventions helps individuals at risk for a genetic disorder to understand the consequences and nature of the disorder, the probability of developing or transmitting it, and the options open to them in management and family planning ${ }^{(14)}$.

Other measures of prevention have approved its efficacy in decreasing the incidence of genetic and congenital disorders for example, discouragement of pregnancy at advanced ages, periconception folic acid supplementation or multivitamin fortification of basic foodstuffs, and avoidance of alcohol consumption and smoking during pregnancy ${ }^{(15)}$. Also, improving level of genetic literacy among the public and considering their demographic, cultural and religious characteristics while planning prevention programs offers more engagement and compliance from the public towards preventive measures of genetic diseases ${ }^{(13)}$. 
Genetic and genomic advances improve the ability to predict disease susceptibility, provide individualized preventive screening, risk reduction interventions, and target disease treatment. Understanding of genetic disorders, variability, mechanisms, their contribution to common diseases, and development of modern genetic testing capabilities have enabled people to assume greater responsibility towards their own health. Thus, the role of health professionals in providing non-directive counseling about inherited traits is one of the representative features of this new era ${ }^{(16)}$.

The term genetic counseling means helping people understand and adapt to the medical, psychological, and familial implications of genetic contributions to disease ${ }^{(17)}$. Genetic counseling is the process by which patients or relatives who are at risk of an inherited disorder, are advised of the consequences and nature of the disorder, the probability of developing or transmitting it, and the options open to them in management and family planning ${ }^{(18,14)}$. Genetic counselors discussing genetic information with clients in an understandable and compassionate manner and ensure that clients understand the risks and benefits of healthcare choices, while maintains confidentiality of genetic information pertaining to their clients ${ }^{(18)}$.
Adulthood is a period of qualitative change, of discontinuity, and of transformation of an earlier life pattern. Entering adult world begins in early 20s and extends until late 20s. The focus of this period is on exploration and provisional commitment to adult roles and responsibilities. First job, marriage, and birth of children are crucial life events which remarks this period, hence knowledge regarding genetic disorders and genetic counseling is essential for university students as they beginning their adulthood where important health related decisions are imposing themselves, that will have a desired impact on their personal health and on society as a whole over the next few decades ${ }^{(19)}$.

Community health nurses are at the interface of translating genetic and genomic advances into effective health care options. They assess individual and family genetic risk factors, provide genetic education and counseling, facilitate referral to a genetic specialist when red flags of a genetic disease are identified. Work in collaboration with other health care providers to offer genetic health care services to individual, family or to the community as a whole ${ }^{(20,21)}$.

\section{Significant of the study}

With the explosive growth of genomic approaches into health care comes the 
realization that the current genetic and genomic education do not adequately prepare community individuals to understand genomic health issues. Individuals understanding of the role of genetics and genomics in disease risk is the key to appropriate disease prevention and detection. Also, health professionals are challenged to translate genomic knowledge and applications into public health and clinical practice that promote health and prevent disease.

\begin{abstract}
Aim of the study
The aim of this study was to assess awareness toward genetic disorders and genetic counseling among Tanta University students.
\end{abstract}

\section{Research question}

What is level of knowledge and attitudes toward genetic disorders and genetic counseling among Tanta university students?

\section{Subjects and Method}

\section{Study design}

Descriptive cross-sectional study design was used in this study.

Setting: This study was conducted in medical and non-medical Faculties of Tanta University. Four Faculties were selected randomly through simple random technique; Faculty of Nursing \& Faculty of Pharmacy were selected from medical faculties and Faculty of Arts \& Faculty of
Engineering were selected from nonmedical Faculties.

Subjects: Thirteen-point eight percent $(13.8 \%)$ of students in the fourth academic year from each faculty was included in the study. They were selected through equal proportion allocation technique. Subjects of the sample were selected by obtaining lists of students' names admitted to fourth academic year from department of Students' Affairs in each Faculty. Stratified random sampling technique was used to select 1005 of students to be included in the study.

\section{Tools of the study}

Two tools were used by the researchers to collect required data for this study.

\section{Tool (I): Knowledge of university} students regarding genetic disorders and genetic counseling.

A structured interview schedule was developed by the researchers based on review of related literature ${ }^{(22-25)}$. It included the following four parts:

Part I: Socio-demographic characteristics of students:

The aim of this part was to collect sociodemographic data about university students such as age, sex, residence, field of study and marital status.

\section{Part II: Knowledge of university} students regarding genetic disorders:

Eleven questions were applied to students 
in this part to collect essential assessment data about definition, types, examples, causes, risk factors, diagnosis, treatment and prevention of genetic disorders.

Part III: Knowledge of university students regarding genetic counseling:

Sex questions were applied to students in this part to collect essential assessment data about definition, process, importance, purpose, at risk group and providers of genetic counseling.

Scoring system of total knowledge scores:

Each question was scored 2 points for complete correct answer, 1 point for incomplete correct, and 0 point for don't know answer. The total score was classified as follow: -

- Good $\rightarrow \quad>70 \%$ of total knowledge score.

- Fair $\rightarrow 60-70 \%$ of the total knowledge score.

- Poor $\rightarrow<60 \%$ of total knowledge score.

- Part IV: Sources of university students' information regarding genetic disorders and genetic counseling such as school, internet, friends, neighbors, media, health care providers, and relatives.

Tool (II): Attitude of university students towards genetic disorders and genetic counseling.
The tool was developed by the researchers based on review of related literature ${ }^{(88,99}$, 107-112), it consisted of thirteen statements to assess students' attitude towards genetic disorders and genetic counseling. Scoring of attitude statements was done through a three-point Likert Scale (Agree (2), neutral (1), and disagree (0). Statements number 2, 4,7 , and 12 reflected negative attitude and scored (0) point for agree, (1) point for neutral and (2) points for disagree with the statement. The total score of attitude statements was calculated and equaled to 26 points and students' attitudes were classified into two categories: -

- Positive attitude $\rightarrow>60 \%$ of total attitude score.

- Negative attitude $\rightarrow \leq 60 \%$ of total attitude score.

\section{Method}

1- An official permission to conduct the study was obtained from deans of Faculty of Nursing, Faculty of Pharmacy, Faculty of Engineering, and Faculty of Arts to facilitate researcher work in collecting required data for the study.

2- Ethical consideration: -

- An approval of Ethical Committee, Faculty of Nursing, Tanta University was obtained to conduct this study.

- Confidentiality and privacy were put in to consideration regarding the data collected. 
- The nature of the study caused no harm to the subjects under study.

- An informed consent was obtained from the selected students to participate in the study.

- Every student was informed about purpose, nature and benefits of the study at beginning of the interview.

3- The study tools were developed by the researcher based on review of related literature.

4- The study tools were tested for content validity by a jury of eight expertise in the field of Community Health Nursing (3 professors of Public Health at Faculty of Medicine, and 5 professors of Community Health at Faculty of Nursing in Tanta university) and was calculated to be equal to $95 \%$ for each of knowledge and attitude according to opinions of expertise.

5- A pilot study was carried out on 100 students of Tanta University to test clarity and feasibility of tools and to determine length of time needed to collect the data from each student. There were no required modifications for tools according to the pilot study. Those students were excluded from the actual survey.

6- Reliability of the tool was equal to 86.5 as calculated according to Cronbach's alpha test.
7- Tools were administered individually to all students to fill it in their Faculty according to the schedule of their lectures and sessions.

8- The average time spent for each student to fill the questionnaire was 20 to30 minutes.

9- Collection of the data took during period of 3 months, from October toDecember 2019.

\section{0- Statistical analysis}

The collected data were organized, tabulated and statistically analyzed using SPSS version 19. For quantitative data, the range, mean, and standard deviation were calculated and for categorical variables, numbers and percentages were calculated. The differences between subcategories were tested by chi square $\left(\mathrm{X}^{2}\right)$, when chi square was not appropriate Monte Carlo exact test was used. The correlation between variables was evaluated using Pearson's correlation coefficient (r) and the significance of results was adopted at $\mathrm{p}<$ $0.05 \%$.

\section{Results}

Table (1) Distribution of studied students by their personal sociodemographic characteristics. It shows that, the age of studied students ranged from 20 to 26 years with a mean of $21.91 \pm 0.96$. Nearly two thirds $(63.7 \%)$ of studied students were females, while males 
represented slightly more than one third $(36.3 \%)$ of the studied sample. Also, nearly two thirds $(63.8 \%)$ of students had rural residence, while slightly more than one third $(36.2 \%)$ of them urban residence. In relation to field of study, Faculty of Arts represented nearly two thirds $(63.1 \%)$ of studied students, followed by Faculty of Pharmacy represented (16.2\%) of students, and Faculty of Engineering represented $(12.3 \%)$ of students, while Faculty of Nursing represented the minority $(8.4 \%)$ of students in the sample. As regard to marital status, more than two thirds $(69.7 \%)$ of students were single, about one quarter $(24.6 \%)$ were engaged, and the minority $(5.2 \%, 0,6 \%)$ of students were married.

Table (2) Represents distribution of studied students by their responses to knowledge assessment of genetic disorders. It shows that, more than one third $(36.7 \%)$ of students had correct answers on definition of genetic disorders while, about two thirds $(63.3 \%)$ of them mentioned don't know answers. Regarding types and common examples of genetic disorders more than two thirds $(67.2 \%$ and $66 \%$ ) of them had incomplete correct answers respectively.

In relation to causes of genetic disorders, more than one third $(37.7 \%)$ of students mentioned complete correct answers, near to one third (31.7\%) mentioned incomplete correct answers and about one third (30.6\%) don't know the answer. As regard to risk factors of genetic disorders, the minority $(4.9 \%)$ of students reported complete correct answers, about two thirds $(66.9 \%)$ reported incomplete correct answers and more than one quarter $(28.2 \%)$ of them don't know the answer. In addition, only one fifth (20.2\%) of students had correct answers on the meaning of a positive genetic testing results, and just about one third $(34.8 \%)$ of them had correct answers on the time during which the environment can influence on gene expression. In relation to screening method of genetic disorders, a minority $(4.6 \%)$ of students gave complete correct answers, while more than two thirds $(67.2 \%)$ of them had incomplete correct answers. Regarding method used in treatment of genetic diseases, the minority $(7.2 \%)$ of students mentioned complete correct answer and less than half $(41.5 \%)$ of them mentioned incomplete correct answers while, more than half $(51.3 \%)$ of students mentioned don't know. Concerning available newborn screening programs, more than half $(52.9 \%)$ of students don't know about the mentioned programs.

More than one third $(38.1 \%)$ of students gave complete correct answers about common preventive measures of genetic disorders, and also more than one third (38.6\%) of them gave incomplete correct answers while, about one quarter $(23.3 \%)$ of students reported don't know answers.

Table (3) Distribution of studied students by their responses to knowledge assessment of genetic counseling. It reveals that, in relation to genetic counseling, less than half $(41.1 \%)$ of students gave correct answers on definition of genetic counseling while, more than half $(58.9 \%)$ of them reported don't know. Regarding the cases that need genetic counseling, a minority $(8.9 \%)$ of students mentioned complete correct answers, half $(51.3 \%)$ of them gave incomplete correct answers and more than third (39.8\%) reported don't know. 
Regarding genetic counseling providers, more than half $(60.3 \%)$ of students reported the correct answer, while more than third $(39.7 \%)$ of them mentioned don't know answers. Concerning the role of genetic counselors, half $(50.2 \%)$ of students mentioned incorrect or don't know answers, more than one third $(39.7 \%)$ reported incomplete answers. As regards to importance of genetic counseling, half $(50.4 \%)$ of students mentioned complete correct answer, more than one quarter $(29.5 \%)$ had incomplete correct answers and one fifth (20.1\%) of them reported don't know. As regard to purpose of genetic counseling, less than half $(42.5 \%)$ of students reported complete correct answer, more than one third (34.9\%) had incomplete correct answers and less than one quarter $(22.6 \%)$ reported don't know.

Table (4) Distribution of studied students in relation to their levels of total knowledge scores of genetic disorders and genetic counseling. It shows that, the majority $(77.6 \%)$ of studied students had poor total knowledge scores, while the minority (12.4\%) of them attained fair total knowledge scores as well as a minority (10\%) of students attained good total knowledge scores regarding genetic disorders and genetic counseling. More than three quarters (78.2\%) of students had poor knowledge scores of genetic disorders, $60.3 \%$ of students had poor knowledge scores of genetic counseling, and the minority $(8.5 \%$, $11.1 \%$ ) of them attained good knowledge scores regarding genetic disorders and genetic counseling respectively.

Table (5) Distribution of studied students in relation to their sources of information regarding genetic disorders and genetic counseling and their awareness about availability of genetic counseling clinics. It shows that, more than half $(50.6 \%)$ of students reported that genetic counseling clinics are unavailable, and more than one third $(36.7 \%)$ didn't know about these clinics. only the minority $(12.7 \%)$ of students reported that genetic counseling clinics are available.

In relation to sources of information regarding genetic disorders, half (54.2\%) of students reported internet, followed by more than one third $(38.7 \%)$ reported school, and the minority $(19.9 \%, 13.4 \%$, $9.5 \%, 8.9 \%, 4.1 \%)$ of students reported media (Newspapers, magazines TV\& radio), health care providers, friends, neighbors and relatives respectively. In relation to sources of information about genetic counseling, three quarters $(75 \%)$ of students reported that they hadn't any source of information about genetic counseling.

Table (6) Distribution of studied students in relation to their attitude toward genetic disorders and genetic counseling. It shows that, the majority $(74.5 \%, 83.2 \%)$ of students agreed to integrate genetic disorders and genetic counseling issues into university education, and they believed in genetic testing and genetic counseling for prevention of genetic diseases respectively. About two thirds $(62.9 \%, 65.8 \%)$ of students accept to use genetic counseling service and assess their genetic risk when needed and agreed to inform relatives (brothers \& sisters) in case of carrying an inherited disease respectively. More than half $(59.2 \%, 56.8 \%)$ of students agreed that genetic counseling is online with 
values of society and they refuse marriage if the partner was a carrier of an inherited disease respectively. In addition, about half $(50.8 \%, 45.5 \%)$ of students agreed that genetic diseases cause chronic disability and can be prevented respectively.

It was observed from the table that, a sizable minority of students expressed their neutral opinions toward most of attitude statements. about one fifth $(20 \%, 19.5 \%$, $20.1 \%$ ) of students were neutral toward attending genetic counseling session, disclosure of genetic information with their families and conducting predictive testing of chronic diseases respectively. One quarter $(25.1 \%)$ of students were neutral toward completing marriage in presence of a genetic risk (I accept to marry a genetic disease carrier). Also, a number of students disagreed with many of attitude statements. About one fifth (19.6\%) of students didn't prefer to know their genetic risk, less than one fifth $(14.7 \%)$ of students disagreed to share genetic information with their relatives. Also, near to one quarter $(23.4 \%)$ of students found conflict between genetic counseling and the values of their society and about one fifth $(18.1 \%)$ of them accept completing marriage in presence of a genetic risk (I accept to marry a genetic disease carrier).

Table (7) Distribution of studied students in relation to their levels of total attitude scores toward genetic disorders and genetic counseling. It shows that, the majority $(87.2 \%)$ of studied students had positive attitude toward genetic disorders and genetic counseling. The minority $(12.8 \%)$ of students had negative attitude.

Table (8) Represents the relationship between personal socio-demographic characteristics of studied students and their total levels of knowledge and attitude scores regarding genetic disorders and genetic counseling. It shows that, there was a significant statistical relation between sex, field of the study and marital status of studied students and their total knowledge scores ( $\mathrm{p}=$ 0.001). There was no significant statistical relation between residence of students and their total knowledge scores regarding genetic disorders and genetic counseling. $(\mathrm{p}=0.372)$.

In relation to the relation between sociodemographic characteristics of the students and their total attitude scores toward genetic disorders and genetic counseling. It shows that, there is a significant statistical relation between sex and field of the study of students and their total attitude scores towards genetic disorders and genetic counseling $(p=0.001)$. while, there is no significant statistical relation between residence and marital status for studied students and their total attitude scores of students towards genetic disorders and genetic counseling, $(p=0.593$ and 0.413 respectively ).

Figure (1) Correlation between total knowledge scores and total attitude scores regarding genetic disorders and genetic counseling. The figure revealed a positive correlation between total knowledge scores and total attitude scores ( $\mathrm{r}=0.295, \mathrm{p}=0.001)$ of genetic disorders and genetic counseling. 
Table (1): Distribution of the studied students by their personal socio-demographic characteristics

\begin{tabular}{|c|c|c|}
\hline \multirow{2}{*}{$\begin{array}{c}\text { Socio-demographic characteristics } \\
\text { students }\end{array}$} & \multicolumn{2}{|c|}{ The studied students $(\mathrm{n}=\mathbf{1 0 0 5})$} \\
\hline & $\mathbf{N}$ & $\%$ \\
\hline Age in years & & \\
\hline$-\quad 20 \leq 22$ & 753 & 74.9 \\
\hline$-\quad>22$ & 252 & 25.1 \\
\hline - Range & \multirow{2}{*}{\multicolumn{2}{|c|}{$\begin{array}{c}20-26 \\
21.91 \pm 0.96\end{array}$}} \\
\hline - $\quad$ Mean+SD & & \\
\hline - Sex: & & \\
\hline - Males & 365 & 36.3 \\
\hline - $\quad$ Females & 640 & 63.7 \\
\hline Residence: & & \\
\hline - Urban & 364 & 36.2 \\
\hline - $\quad$ Rural & 641 & 63.8 \\
\hline \multicolumn{3}{|l|}{ Field of study: } \\
\hline - Nursing & 84 & 8.4 \\
\hline - Pharmacy & 163 & 16.2 \\
\hline - $\quad$ Engineering & 124 & 12.3 \\
\hline - Arts & 634 & 63.1 \\
\hline \multicolumn{3}{|l|}{ Marital status: } \\
\hline - $\quad$ Single & 699 & 69.6 \\
\hline - $\quad$ Engaged & 248 & 24.6 \\
\hline - $\quad$ Married & 52 & 5.2 \\
\hline - $\quad$ Divorced & 6 & 0.6 \\
\hline
\end{tabular}


Table (2): Distribution of studied students by their responses to knowledge assessment of genetic disorders

\begin{tabular}{|c|c|c|}
\hline \multirow{2}{*}{ Knowledge of genetic disorders } & \multicolumn{2}{|c|}{ The studied students $(n=1005)$} \\
\hline & $\mathbf{N}$ & $\%$ \\
\hline $\begin{array}{l}\text { Definition of genetic disorders: } \\
-\quad \text { Don't know } \\
-\quad \text { Correct }\end{array}$ & $\begin{array}{l}636 \\
369\end{array}$ & $\begin{array}{l}63.3 \\
36.7\end{array}$ \\
\hline $\begin{array}{l}\text { Types of genetic disorders: } \\
-\quad \text { Don't know } \\
-\quad \text { Correct and incomplete } \\
-\quad \text { Correct and complete }\end{array}$ & $\begin{array}{c}284 \\
675 \\
45\end{array}$ & $\begin{array}{c}28.3 \\
67.2 \\
4.5\end{array}$ \\
\hline \begin{tabular}{ll}
\multicolumn{2}{l}{ Examples of genetic disorders: } \\
- & Don't know \\
- & Correct and incomplete \\
- & Correct and complete
\end{tabular} & $\begin{array}{l}204 \\
663 \\
138\end{array}$ & $\begin{array}{l}20.3 \\
66.0 \\
13.7\end{array}$ \\
\hline $\begin{array}{l}\text { Causes of genetic disorders: } \\
-\quad \text { Don't know } \\
-\quad \text { Correct and incomplete } \\
-\quad \text { Correct and complete }\end{array}$ & $\begin{array}{l}308 \\
318 \\
379\end{array}$ & $\begin{array}{l}30.6 \\
31.7 \\
37.7\end{array}$ \\
\hline $\begin{array}{l}\text { Risk factors for genetic disorders: } \\
\text { - } \quad \text { Don't know } \\
\text { - } \quad \text { Correct and incomplete } \\
\text { - } \quad \text { Correct and complete }\end{array}$ & $\begin{array}{c}283 \\
672 \\
49\end{array}$ & $\begin{array}{c}28.2 \\
66.9 \\
4.9\end{array}$ \\
\hline $\begin{array}{l}\text { A positive genetic test of a mutation means: } \\
-\quad \text { Don't know } \\
-\quad \text { Correct }\end{array}$ & $\begin{array}{l}802 \\
203\end{array}$ & $\begin{array}{l}79.8 \\
20.2\end{array}$ \\
\hline $\begin{array}{l}\text { Time when the environment influence } \\
\text { expression of genes } \\
\text { - Don't know } \\
-\quad \text { Correct }\end{array}$ & $\begin{array}{l}655 \\
350\end{array}$ & $\begin{array}{l}65.2 \\
34.8\end{array}$ \\
\hline $\begin{array}{l}\text { Screening methods of genetic disorders: } \\
-\quad \text { Don't know } \\
-\quad \text { Correct and incomplete } \\
-\quad \text { Correct and complete }\end{array}$ & $\begin{array}{c}283 \\
675 \\
46\end{array}$ & $\begin{array}{c}28.2 \\
67.2 \\
4.6\end{array}$ \\
\hline $\begin{array}{l}\text { Methods used in treatment of genetic counseling: } \\
-\quad \text { Don't know } \\
-\quad \text { Correct and incomplete } \\
-\quad \text { Correct and complete }\end{array}$ & $\begin{array}{c}516 \\
417 \\
72\end{array}$ & $\begin{array}{c}51.3 \\
41.5 \\
7.2\end{array}$ \\
\hline $\begin{array}{l}\text { Available newborn screening programs } \\
-\quad \text { Don't know } \\
-\quad \text { Correct and incomplete } \\
-\quad \text { Correct and complete } \\
\end{array}$ & $\begin{array}{r}532 \\
195 \\
278 \\
\end{array}$ & $\begin{array}{r}52.9 \\
19.4 \\
27.7\end{array}$ \\
\hline $\begin{array}{l}\text { Prevention of genetic disorders } \\
-\quad \text { Don't know } \\
-\quad \text { Correct and incomplete } \\
-\quad \text { Correct and complete }\end{array}$ & $\begin{array}{l}234 \\
388 \\
383\end{array}$ & $\begin{array}{l}23.3 \\
38.6 \\
38.1\end{array}$ \\
\hline
\end{tabular}


Table (3): Distribution of studied students by their responses to knowledge assessment of genetic counseling

\begin{tabular}{|c|c|c|}
\hline \multirow[t]{2}{*}{ Knowledge of genetic counseling } & \multicolumn{2}{|c|}{$\begin{array}{l}\text { The studied students } \\
\qquad(\mathrm{n}=1005)\end{array}$} \\
\hline & $\mathbf{N}$ & $\%$ \\
\hline $\begin{array}{l}\text { Definition of genetic counseling } \\
-\quad \text { Don't know } \\
-\quad \text { Correct }\end{array}$ & $\begin{array}{l}592 \\
413\end{array}$ & $\begin{array}{l}58.9 \\
41.1\end{array}$ \\
\hline $\begin{array}{l}\text { To whom the services of genetic } \\
\text { counseling should be provided } \\
\text { - Don't know } \\
\text { - } \quad \text { Correct and incomplete } \\
-\quad \text { Correct and complete }\end{array}$ & $\begin{array}{c}400 \\
516 \\
89\end{array}$ & $\begin{array}{c}39.8 \\
51.3 \\
8.9\end{array}$ \\
\hline $\begin{array}{l}\text { Provider of genetic counseling } \\
-\quad \text { Don't know } \\
-\quad \text { Correct }\end{array}$ & $\begin{array}{l}399 \\
606\end{array}$ & $\begin{array}{l}39.7 \\
60.3\end{array}$ \\
\hline $\begin{array}{l}\text { Role of genetic counselors: } \\
-\quad \text { Don't know } \\
-\quad \text { Correct and incomplete } \\
-\quad \text { Correct and complete }\end{array}$ & $\begin{array}{l}505 \\
399 \\
101\end{array}$ & $\begin{array}{l}50.2 \\
39.7 \\
10.0\end{array}$ \\
\hline $\begin{array}{l}\text { Importance of genetic counseling: } \\
-\quad \text { Don't know } \\
-\quad \text { Correct and incomplete } \\
-\quad \text { Correct and complete }\end{array}$ & $\begin{array}{l}202 \\
296 \\
507\end{array}$ & $\begin{array}{l}20.1 \\
29.5 \\
50.4\end{array}$ \\
\hline $\begin{array}{l}\text { Purposes of genetic counseling: } \\
-\quad \text { Don't know } \\
-\quad \text { Correct and incomplete } \\
-\quad \text { Correct and complete }\end{array}$ & $\begin{array}{l}227 \\
351 \\
427\end{array}$ & $\begin{array}{l}22.6 \\
34.9 \\
42.5\end{array}$ \\
\hline
\end{tabular}

Table (4): Distribution of studied students according to their levels of total knowledge scores of genetic disorders and genetic counseling

\begin{tabular}{|l|c|c|c|c|c|c|}
\hline \multirow{2}{*}{ Total scores of knowledge } & \multicolumn{2}{|c|}{ Studied students' levels of total knowledge scores } \\
\cline { 2 - 7 } & \multicolumn{2}{|c|}{ Poor } & \multicolumn{2}{c|}{ Fair } & \multicolumn{2}{c|}{ Good } \\
\cline { 2 - 7 } & $\mathrm{n}$ & $\%$ & $\mathrm{n}$ & $\%$ & $\mathrm{~N}$ & $\%$ \\
\hline $\begin{array}{l}\text { Total scores of knowledge } \\
\text { about genetic disorders }\end{array}$ & 786 & 78.2 & 134 & 13.3 & 85 & 8.5 \\
\hline $\begin{array}{l}\text { Total scores of knowledge } \\
\text { about genetic counseling }\end{array}$ & 606 & 60.3 & 287 & 28.6 & 112 & 11.1 \\
\hline $\begin{array}{l}\text { Total scores of knowledge } \\
\text { about genetic disorders } \\
\text { genetic counseling }\end{array}$ & 780 & 77.6 & 125 & 12.4 & 100 & 10.0 \\
\hline
\end{tabular}

Vol. 21 No. 2 (Suppl) May, 2021 
Table (5): Distribution of studied students according to their sources of information about genetic disorders and genetic counseling and their awareness about availability of genetic counseling clinics

\begin{tabular}{|c|c|c|}
\hline \multirow{2}{*}{$\begin{array}{l}\text { Sources of information regarding genetic } \\
\text { disorders and genetic counseling }\end{array}$} & \multicolumn{2}{|c|}{$\begin{array}{l}\text { The studied students } \\
\qquad(\mathrm{n}=1005)\end{array}$} \\
\hline & $\mathbf{N}$ & $\%$ \\
\hline $\begin{array}{l}\text { Availability of genetic counseling clinics } \\
-\quad \text { Yes } \\
-\quad \text { No } \\
-\quad \text { Don't know }\end{array}$ & $\begin{array}{l}127 \\
509 \\
369\end{array}$ & $\begin{array}{l}12.7 \\
50.6 \\
36.7\end{array}$ \\
\hline $\begin{array}{ll}* \text { Sources of information of genetic disorders: } \\
-\quad \text { Internet } \\
-\quad \text { School } \\
-\quad \text { Friends } \\
-\quad \text { Neighbors } \\
-\quad \text { Health care providers } \\
-\quad \text { Newspapers, magazines, TV\& radio } \\
-\quad \text { Relatives } \\
-\quad \text { None }\end{array}$ & $\begin{array}{l}545 \\
389 \\
95 \\
89 \\
135 \\
200 \\
41 \\
195\end{array}$ & $\begin{array}{l}54.2 \\
38.7 \\
9.5 \\
8.9 \\
13.4 \\
19.9 \\
4.1 \\
19.4\end{array}$ \\
\hline $\begin{array}{ll}* \text { Sources of information of genetic counseling } \\
-\quad \text { Internet } \\
-\quad \text { School } \\
-\quad \text { Friends } \\
-\quad \text { Neighbors } \\
-\quad \text { Health care providers } \\
-\quad \text { Newspapers, magazines, TV\& radio } \\
-\quad \text { Relatives } \\
-\quad \text { None }\end{array}$ & $\begin{array}{l}179 \\
94 \\
16 \\
16 \\
47 \\
66 \\
6 \\
754\end{array}$ & $\begin{array}{l}17.8 \\
9.4 \\
1.6 \\
1.6 \\
4.7 \\
6.6 \\
0.6 \\
75.0\end{array}$ \\
\hline
\end{tabular}

*More than one answer. 
Table (6): Distribution of studied students according to their attitude towards genetic disorders and genetic counseling

\begin{tabular}{|c|c|c|c|c|c|c|}
\hline \multirow{3}{*}{$\begin{array}{l}\text { Attitude statements of genetic disorders and genetic } \\
\text { counseling }\end{array}$} & \multicolumn{6}{|c|}{ The studied students $(n=1005)$} \\
\hline & \multicolumn{2}{|c|}{ Disagree } & \multicolumn{2}{|c|}{ Neutral } & \multicolumn{2}{|c|}{ Agree } \\
\hline & $\mathrm{N}$ & $\%$ & $\mathrm{n}$ & $\%$ & $\mathrm{n}$ & $\%$ \\
\hline Genetic disease causes chronic disability. & 223 & 22.2 & 271 & 27.0 & 511 & 50.8 \\
\hline Genetic diseases are not preventable. & 457 & 45.5 & 297 & 29.6 & 251 & 25.0 \\
\hline $\begin{array}{l}\text { Genetic counseling and genetic testing are } \\
\text { important to prevent genetic diseases. }\end{array}$ & 64 & 6.4 & 105 & 10.4 & 836 & 83.2 \\
\hline I accept to marry a genetic disease carrier. & 571 & 56.8 & 252 & 25.1 & 182 & 18.1 \\
\hline $\begin{array}{l}\text { Provision of genetic testing service in health } \\
\text { insurance hospitals will reduce the spread of genetic } \\
\text { disorders in the community. }\end{array}$ & 125 & 12.4 & 190 & 18.9 & 690 & 68.7 \\
\hline $\begin{array}{l}\text { At some point in my life, I might consider having a } \\
\text { genetic counselling to find out my risk of } \\
\text { developing genetic diseases. }\end{array}$ & 137 & 13.6 & 236 & 23.5 & 632 & 62.9 \\
\hline $\begin{array}{l}\text { It is better that a person does not know whether he } \\
\text { has the gene for a chronic disease or not. }\end{array}$ & 606 & 60.3 & 202 & 20.1 & 197 & 19.6 \\
\hline $\begin{array}{l}\text { If I had a family history of a serious genetic disease, } \\
\text { I would definitely want to use prenatal genetic } \\
\text { diagnosis. }\end{array}$ & 68 & 6.8 & 143 & 14.2 & 794 & 79.0 \\
\hline $\begin{array}{l}\text { I would inform my brothers and sisters of a DNA } \\
\text { test result indicating, I carry an inherited disease. }\end{array}$ & 148 & 14.7 & 196 & 19.5 & 661 & 65.8 \\
\hline $\begin{array}{l}\text { I think that premarital genetic counseling and } \\
\text { genetic testing are necessary in case of } \\
\text { consanguinity }\end{array}$ & 111 & 11.0 & 184 & 18.3 & 710 & 70.6 \\
\hline $\begin{array}{l}\text { I accept to attend genetic counseling sessions and } \\
\text { following advice provided for me. }\end{array}$ & 109 & 10.8 & 201 & 20.0 & 695 & 69.2 \\
\hline Genetic counseling opposes the values of society. & 595 & 59.2 & 175 & 17.4 & 235 & 23.4 \\
\hline $\begin{array}{l}\text { It is better to integrate issues of genetic disorders } \\
\text { and genetic counseling into university education. }\end{array}$ & 103 & 10.2 & 153 & 15.2 & 749 & 74.5 \\
\hline
\end{tabular}


Table (7): Distribution of studied students according to their levels of total attitude scores toward genetic disorders and genetic counseling

\begin{tabular}{|c|c|c|}
\hline \multirow{2}{*}{$\begin{array}{c}\text { Levels of total attitude scores of genetic disorders } \\
\text { and genetic counseling }\end{array}$} & $\mathrm{N}$ & $\%$ \\
\cline { 2 - 3 } & $1005)$ \\
\hline$-\quad$ Negative attitude & 129 & 12.8 \\
\hline$-\quad$ Positive attitude & 876 & 87.2 \\
\hline
\end{tabular}

Table (8): Relationship between personal socio-demographic characteristics of studied students and their total levels of knowledge and attitude scores regarding genetic disorders and genetic counseling

\begin{tabular}{|c|c|c|c|c|c|c|c|c|c|c|c|c|}
\hline \multirow{3}{*}{$\begin{array}{c}\text { Socio-demographic } \\
\text { characteristics of } \\
\text { students }\end{array}$} & \multicolumn{6}{|c|}{ Levels of total knowledge scores } & \multirow{3}{*}{$\begin{array}{l}\mathbf{X}^{2} \\
\mathbf{p}\end{array}$} & \multicolumn{4}{|c|}{ Level of Total Attitude Score } & \multirow{3}{*}{$\begin{array}{l}\mathbf{X}^{2} \\
\mathbf{P}\end{array}$} \\
\hline & \multicolumn{2}{|c|}{ Poor } & \multicolumn{2}{|c|}{ Fair } & \multicolumn{2}{|c|}{ Good } & & \multicolumn{2}{|c|}{ Negative } & \multicolumn{2}{|c|}{ Positive } & \\
\hline & $\mathbf{N}$ & $\%$ & $\mathbf{N}$ & $\%$ & $\mathbf{N}$ & $\%$ & & $\mathbf{N}$ & $\%$ & $\mathbf{N}$ & $\%$ & \\
\hline $\begin{array}{ll}- & \text { Sex } \\
- & \text { Males } \\
- & \text { Females }\end{array}$ & $\begin{array}{l}311 \\
469\end{array}$ & $\begin{array}{l}85.2 \\
73.3\end{array}$ & $\begin{array}{l}38 \\
87\end{array}$ & $\begin{array}{l}10.4 \\
13.6\end{array}$ & $\begin{array}{l}16 \\
84\end{array}$ & $\begin{array}{l}4.4 \\
13.1\end{array}$ & $\begin{array}{l}24.001 \\
0.001 *\end{array}$ & $\begin{array}{l}68 \\
61\end{array}$ & $\begin{array}{l}18.6 \\
9.5\end{array}$ & $\begin{array}{l}297 \\
579\end{array}$ & $\begin{array}{l}81.4 \\
90.5\end{array}$ & $\begin{array}{l}17.200 \\
0.001 *\end{array}$ \\
\hline \begin{tabular}{lc}
\multicolumn{2}{l}{ Residence: } \\
$-\quad$ Urban \\
$-\quad$ Rural
\end{tabular} & $\begin{array}{l}291 \\
489\end{array}$ & $\begin{array}{l}79.9 \\
76.3\end{array}$ & $\begin{array}{l}39 \\
86\end{array}$ & $\begin{array}{l}10.7 \\
13.4\end{array}$ & $\begin{array}{l}34 \\
66\end{array}$ & $\begin{array}{l}9.3 \\
10.3\end{array}$ & $\begin{array}{l}1.976 \\
0.372\end{array}$ & $\begin{array}{l}44 \\
85\end{array}$ & $\begin{array}{l}12.1 \\
13.3\end{array}$ & $\begin{array}{l}320 \\
556\end{array}$ & $\begin{array}{l}87.9 \\
86.7\end{array}$ & $\begin{array}{l}0.285 \\
0.593\end{array}$ \\
\hline $\begin{array}{l}\text { Field of study: } \\
-\quad \text { Nursing } \\
-\quad \text { Pharmacy } \\
-\quad \text { Engineering } \\
-\quad \text { Arts }\end{array}$ & $\begin{array}{l}20 \\
48 \\
117 \\
595\end{array}$ & $\begin{array}{l}23.8 \\
29.4 \\
94.4 \\
93.8\end{array}$ & $\begin{array}{l}25 \\
59 \\
7 \\
34\end{array}$ & $\begin{array}{l}29.8 \\
36.2 \\
5.6 \\
5.4\end{array}$ & $\begin{array}{l}39 \\
56 \\
0 \\
5\end{array}$ & \begin{tabular}{l|}
46.4 \\
34.4 \\
0.0 \\
0.8
\end{tabular} & $\begin{array}{l}50.015 \\
0.001 *\end{array}$ & $\begin{array}{l}9 \\
6 \\
30 \\
84\end{array}$ & \begin{tabular}{l|l|l|}
10.7 & \\
3.7 & \\
24.2 & \\
13.2 & & \\
\end{tabular} & $\begin{array}{l}75 \\
157 \\
94 \\
550\end{array}$ & $\begin{array}{l}89.3 \\
96.3 \\
75.8 \\
86.8\end{array}$ & $\begin{array}{l}26.942 \\
0.001 *\end{array}$ \\
\hline $\begin{array}{ll}\text { Marital status: } \\
-\quad \text { Single } \\
-\quad \text { Engaged } \\
-\quad \text { Married } \\
-\quad \text { Divorced }\end{array}$ & $\begin{array}{l}550 \\
177 \\
47\end{array}$ & $\begin{array}{l}78.7 \\
71.4 \\
90.4 \\
100 . \\
0\end{array}$ & $\begin{array}{l}80 \\
40 \\
5\end{array}$ & $\begin{array}{l}11.4 \\
16.1 \\
9.6 \\
0.0\end{array}$ & $\begin{array}{l}69 \\
31 \\
0\end{array}$ & $\begin{array}{l}9.9 \\
12.5 \\
0.0 \\
0.0\end{array}$ & $\begin{array}{c}\text { MCET } \\
0.037 *\end{array}$ & $\begin{array}{l}97 \\
26 \\
6 \\
0\end{array}$ & $\begin{array}{l}13.9 \\
10.5 \\
11.5 \\
0.0\end{array}$ & $\begin{array}{l}602 \\
222 \\
46 \\
6\end{array}$ & $\begin{array}{l}86.1 \\
89.5 \\
88.5 \\
100 . \\
0\end{array}$ & $\begin{array}{l}2.865 \\
0.413\end{array}$ \\
\hline
\end{tabular}

*Significant at $(\mathrm{p} \leq 0.05)$.

MCET=Monte Carlo exact test 


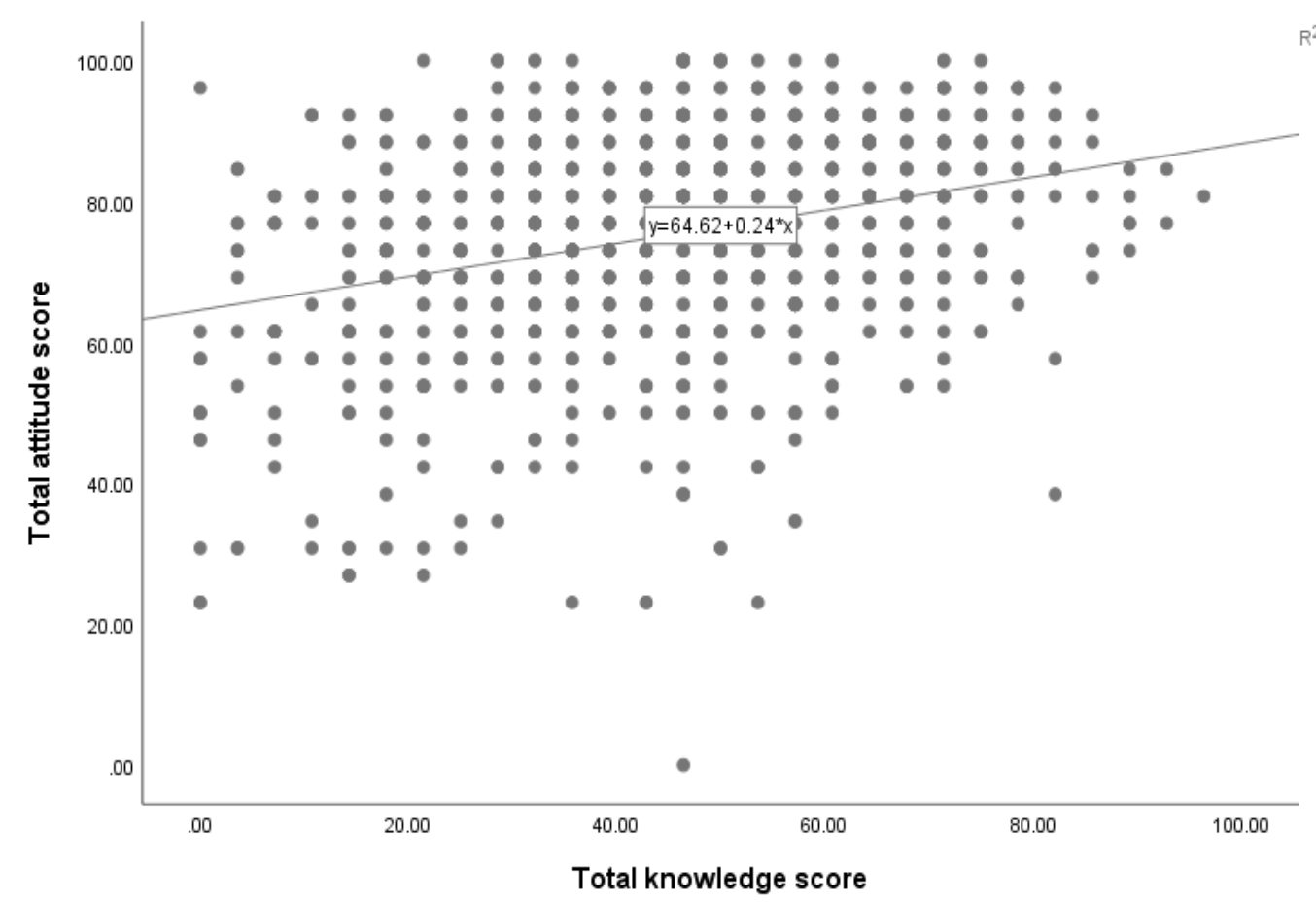

Figure (1): Correlation between total knowledge scores and total attitude scores 


\section{Discussion}

Genetic and genomic sciences offering a new way to be followed in the management of human's health and in a near future it will be the magical option that resolves health problems. University students in early adulthood had the suitable time to make effective decisions in relation to employment, marriage, reproduction, offspring and even the followed lifestyle which all are affected by their health situations ${ }^{(19,26)}$.

The aim of this study is to assess knowledge and attitude of Tanta university students regarding genetic disorders and genetic counseling.

The current study revealed that the majority of studied students' knowledge related to genetic disorders was generally poor. The deficiencies in knowledge were related to most items of assessment concerning definition, types, causes, risk factors, treatment, and prevention of genetic diseases. Results of the current study have come in agreement with Ahmed et al. (2012) ${ }^{(27)}$, who found that, all the studied sample had poor knowledge regarding the reproductive health concepts, fertilization, risk of consanguineous marriage, causes of genetic disorders, transmission of genetic traits from parents to children, and also the primary prevention of genetic disorders.
A study by Abd El Fattah et al. (2015) ${ }^{(3)}$ revealed that the majority of the students had lack of knowledge regarding premarital genetic screening, most of subjects were unaware of being at risk, didn't believe on early checkup, and didn't performed screening and early detection measures before a program on premarital genetic counseling were applied for them. However, a study conducted in Carolina by Haga et al. (2013) ${ }^{(28)}$, revealed a high level of genetic knowledge among the studied participants. The study findings were attributed to an increase in reporting of genetic and genomic research and the permeation of genetics into public culture of this region.

The knowledge deficiency is a serious finding of the present study. Because a high level of genetic knowledge is needed to optimize the understanding of genomic risks, enable informed decision making and enhance individuals' ability to view genetic services as applicable to their own lives. Genomics are a rapidly expanding field. Overtime, new genetic and genomic applications are developed and integrated into clinical practices. This makes it clear that there is a need to support recent formal academic education with the required genetic and genomic information.

In assessing students' knowledge of genetic counseling, a large segment of the sample 
(more than three quarters) in the present study didn't heard of genetic counseling and demonstrated poor level of knowledge. The observed knowledge deficiency revealed a huge gap between the available genetic counseling services and the provided care from this service (outcome of the service). When individuals in their early adulthood don't know about genetic risks and don't heard of genetic counseling, how they will connect themselves to these services. Clients will not request for the service even if a need is there there is no medical complain make them request care.

According to the study done by Riesgraf et al. (2015) ${ }^{(29)}$, about $50 \%$ of genetic counseling clients are self-referred which give clients and patients a substantial and important role in accessing genetic counseling services. In addition, health professional should be able to timely and appropriately make referral for genetic counseling clinics, but the current study revealed knowledge deficiency among medical students too and these involved future nurses. This lack of knowledge makes it difficult to expect adequate genetic nursing care from future nurses which involves genetic risk assessment (risk identification), counseling, and appropriate referral.

The deficiency in knowledge particularly about the scope and purpose of genetic counseling deter nurses from identifying health situations that requires referral for genetic counseling. For these reasons, it is apparent that at-risk individuals don't reach the available genetic services and missing their chance of escaping themselves or their offspring from the disease. The results were supported by Goldberg (2015) ${ }^{(17)}$, who found that the perceived scope of genetic counseling is narrower than the actual field. They recommend increasing awareness about genetic counseling services among the public and allied health professional of various genetic counseling services.

It was obvious from the current findings in the present study that more than one third of students had misconceptions about the purpose of genetic counseling. This is because eugenic movements have no roots in Arabic or other Islamic countries. However, misunderstanding of Islamic rules or personal believes could interfere with seeking of genetic care and limits the expected benefits from genetic services. A study on Omani by Al-Farsi et al. (2014) ${ }^{(30)}$, had the singles showed their willingness to perform the pre-marital carrier testing but they withdrew due to customs and traditions. In addition, most of them showed resistance to consanguineous unions, but other studies on Omani have shown that about half of Omani marriages are among relatives. 
As found by Al- Haddad et al. (2010) ${ }^{(31)}$, a few of students have negative attitudes towards premarital counseling and justify their refusal by the misunderstanding of Islamic rules. Religious and cultural issues should be addressed within the prepared educational initiatives. The results of the present study are in line with Maio (2013) (32), who revealed some area of misconceptions that were related to the perceptions that genetic counseling involves prevention of inheritable diseases, and helping couples to have children with desirable characteristics, but these findings were attributed to eugenic concepts.

Although majority of students had poor knowledge about genetic disorders and genetic counseling, the current results in the present study revealed that, most of students had an overall favorable attitude toward genetic disorders and genetic counseling. A positive correlation has been found between students' total knowledge and total attitude scores. These findings highlighted the students' interest in genetic testing and learning about genetics and genomics which promotes the success of any educational or health initiatives.

The study findings go with a study on Latinos by Hamilton et al. (2016) ${ }^{(25)}$, who revealed the participants' high level of interest in genetic tests for cancer and other disease risks. In addition, a study by Riesgraf et al. (2015) ${ }^{(29)}$ revealed an overall favorable attitude toward genetic counseling. Many of respondents expressed their trust in the information provided by a genetic counselor and saw genetic counseling as in line with their values. However, a study by Abd El Fattah et al. (2015) ${ }^{(3)}$, didn't support the current results, they revealed the negative attitudes that most students had regarding premarital genetic counseling. The negative attitude of students was attributed to fear of unknown and absence of screening culture in Egypt.

The minority of students in this study showed negative attitude toward attitude statements. Issues surrounded unfavorable attitude toward genetic testing and genetic counseling often related to personal, social, and cultural barriers such as misuse of genetic information (genetic discrimination), fear of stigmatization, conflict with personal believes, expected adverse emotional responses to test results, and costs of genetic testing. Riesgraf et al. (2015) ${ }^{(29)}$, found that a sizable minority of respondents would not trust genetic counselors or had conflicts with their own values in relation to using of genetic counseling services.

The current findings highlighted that about one fifth of studied students agreed to proceed with marriage regardless of incompatible test results and this was in addition to one quarter of students who had 
neutral opinions. The results agree with a study on attitude towards premarital carrier screening by Al-Farsi et al. (2014) ${ }^{(30)}$, they found that $15.3 \%$ of participants choose to proceed with marriage even in case of positive testing results. It was noted that, timing of the test had influence on these opinions.

The premarital carrier screening (PMCS) is usually done in the period between the engagement and marriage. An unexpected result may be ignored by couples or their families for various cultural, social, and emotional reasons. Thus, the test should be done at an early stage (school or university stage) so that both couples who decide to marry know the results prior to engagement. May be many of Tanta university students change their opinions if they receive their results of genetic carrier testing.

Furthermore, although the majority of students seemed to agree about prenatal genetic diagnosis, the fact that most of studied students were singles, not engaged, and not married makes them not confronted in reality with issues related to conception and pregnancy. May be their favorable attitude is changed later toward prenatal genetic diagnosis when they are confronted with hard choices regarding invasive diagnostic tests and termination of affected pregnancies.
The socio-demographic characteristics of studied students revealed a number of indicators that influenced their knowledge and attitude toward genetic disorders and genetic counseling. An increase in the level of knowledge and better attitude were observed in association with certain personal and characteristics of students. Higher genetic knowledge and more positive attitude were observed among students that were females and studying in the medical fields. Also, engaged students demonstrated better knowledge than singles students.

Nature of the study in medical fields entails on scientific health information that are directly linked to genetic knowledge, however medical students in the present study demonstrated insufficient level of genetic knowledge. As regards to marital status of students, engaged and married students are more likely to discuss issues related to conception, pregnancy, and healthy children with their families or health professionals.

These findings are in line with AlHaddad et al. (2010) ${ }^{(31)}$, who mentioned that medical students had higher knowledge and attitude scores than nonmedical students regarding premarital counseling. Also, students of the present study who had rural residence demonstrated better knowledge about 
genetic counseling. Perhaps this is because nearly two thirds of students in the studied sample had rural residence and also, the majority of students hadn't any source of information about genetic counseling.

It was observed in the results of this study that female students had better knowledge and attitude than male students. In despite that about two thirds of the studied sample were of female students, this finding reflects the success of efforts made in Egypt for the empowerment of the Egyptian women.

With regard to sources of students' information in the present study, Internet was the primary source of students' information about genetic disorders (more than half of students) and genetic counseling (less than one fifth of them). The school was the second source of students' information after the net, more than third of students mentioned school as their information source about genetic disorders and it was mentioned by the minority as a source of information about genetic counseling. These results agree with Goldberg (2015) ${ }^{(17)}$, who found media the most common source of information about genetic counseling; news was the top source of media responses followed by the internet and television.

In the current study, information sources including friends, neighbors, and relatives were the least reported. These findings are supported by Hamilton et al. (2016) ${ }^{(25)}$, who found that the social networks did not appear to be a common source of genetic testing information, given that this information was considered to be private or of a sensitive nature and were infrequently reported. Furthermore, it wasn't seeming from the present findings that health professional offered adequate genetic information support for the studied students, only a minority of students mentioned them as a source for their information about genetic disorders and genetic counseling.

Al-Farsi et al. (2014) ${ }^{(30)}$, mentioned that health education efforts concerning premarital carrier screening at the primary health centers are carried out by medical and nursing staff while providing service for patients. There are no written policies or protocols that are standardized in practice which would identify the role of medical team members and expected outcomes of the process. These findings pointed at the empty chair of the genetic counseling profession in the health care facilities of Egypt and highlighted the vital role of genetic counselors that is to provide premarital, preconception, and prenatal genetic counseling and genetic counseling for individuals when indicated or even when they wish. 


\section{Conclusion}

The study concluded that, the majority of Tanta University students had poor knowledge regarding genetic disorders and genetic counseling, the majority of them had not heard of genetic counseling. There was a marked lack in the different sources of information whether it was formal sources as schools and health professionals or informal sources as relatives and friends, which constituted the major cause behind the knowledge deficiency. Regardless of the deficient knowledge, most of studied students showed positive attitudes toward genetic disorders and genetic counseling.

\section{Recommendations}

The study recommended the following recommendations.

-Highlighting the importance of family history (a minimum of three generations $\&$ including $1^{\text {st }}, 2^{\text {nd }}$, and $3^{\text {rd }}$ degree relatives), genetic testing and genetic counseling as a mean that is used for prevention of genetic diseases in individuals and their offspring among university students through educational campaign, booklets and brochures.

-Besides, genetic carrier tests of prevalent genetic diseases among Egyptians should be made available for university students with accepted costs and adequate coverage.
- It was more urgent to study about genetic disorders and genetic counseling for all faculties in Tanta University.

-Time have come for the establishment of genetics and genomics nursing department at the faculties of nursing.

- Encourage more future researches in this topics to save the community health lifestyle.

\section{References}

1. Kelly EB. Encyclopedia of human genetics and disease. California: ABC-CLIO; 2013.15, 315-319.

2. Robin SD. Bridges: Genetic disorders, Guangzhou. China: Benchmark Education Company; 2011.2-8.

3. Abd El Fattah H, Soliman SM, Amin FM. Premarital Genetic Counselling among female adolescents students. Journal of American Science. 2015; 11(6):218-25.

4. Encyclopedia Britannica. Human genetic disease. 2019. Available at: https://www.britannica.com/science/h uman-genetic-disease.

5. Tadmouri GO. Genetic disorders in Arab populations. 2019. Available at: https://www.scribd.com/document/11 6140544/Genetic-Disorders-In-inArab-populations-pdf.

6. Tadmouri GO, Sastry KS, Chouchane L. Arab gene geography: At population diversities to personalized 
medical genomics. J. Glob Cardiol Sci. Pract. 2014; 31(4): 394-408.

7. El-Gilany A, Yahia S, Shokeir M, Elmier H. Morbidity profile of children referred to Genetic Unit of Mansoura University Children's Hospital, Egypt. American Journal of Preventive Medicine and Public Health. 2017; 1(1):1-9.

8. Shawky RM, Elsayed NS, Ibrahim DS, Seif Eldin NS. Profile of genetic disorders prevalent in northeast region of Cairo, Egypt. The Egyptian Journal of Medical Human Genetics. 2012; 13(1): 623- 45.

9. KUNA Kuwait News Agency. Genetic diseases cost Arabs USD 13 bln a year. 2018. Available at: https://www.kuna.net.kw/ArticleDetai ls.aspx $? \mathrm{id}=1869979 \&$ language $=\mathrm{en} \#$.

10. Bajaj K, Gross S. Carrier screening: Past, present, and future. J. Clin. Med. 2014; 3(3):1033-42.

11. Tercyak KP. Handbook of genomics and the family psychosocial context for children and adolescents. USA: Springer; 2010. 222-23.

12. CDC. Newborn Screening Portal. 2016. Available at: https://www.cdc. gov/newbornscreening/.

13. Tadmouri GO. Genetic Disorders in Arabs - Center for Arab Genomic Studies. 2010. Available at: http://www.cags.org.ae/cb404c1.pdf.
14. Balobaid A, Qari A, Al-Zaidan H. Genetic counselors' scope of practice and challenges in genetic counseling services in Saudi Arabia. Int. J. Pediatr. Adolesc. Med. 2016; 3(1):16.

15. Kuliev A. Practical preimplantation genetic diagnosis. $2^{\text {nd }}$ ed. USA: Springer; 2012. 1-3, 212.

16. Syurina EV, Brankovic I, ProbstHensch N, Brand A. Genome-Based Health Literacy: A new challenge for Public Health Genomics. Public Health Genomics. 2011; 14(4-5): 201208.

17. Goldberg D. Measuring awareness and identifying misconceptions about genetic counseling services and utilizing television to educate. Master Sc. Thesis. Faculty of Medicine, University of California, Irvine, 2015. https://escholarship.org/content/qt6dr 4r4xx/qt6dr4r4xx_noSplash_21fb49c 5a3aad9c15fb42e49b9fe19ec.pdf.

18. Robinson TR. Genetics for dummies. $2^{\text {nd }} e d$. USA: Wiley; 2010.173-203.

19. Encyclopedia Britannica. Development in Adolescence. 2019. Available at: https://www.britannica. com/topic/human-behavior/ Development-in-adolescence.

20. Lancaster J, Stanhope M. Public Health Nursing: Population-Centered Health Care in the Community. $9^{\text {th }}$ ed. 
USA: Elsevier Health Sciences; 2015. 250-251.

21. Greco KE, Tinley S, Seibert D. Essential Genetic and Genomic Competencies. USA: American Nurses Association and International Society of Nurses in Genetics. 2011. http://www.nursingworld.org/MainM enuCategories/EthicsStandards/Genet icsCDC.

22. Temtamy SA, Hussen DF. Genetics and Genomic Medicine in Egypt: Steady pace. Mol. Genet Genomic Med. 2017; 5(1): 8-14.

23. Yang M, Kim J. Principles of genetic counseling in the Era of NextGeneration Sequencing. Ann Lab Med. 2018; 38: 291-295.

24. Hamilton GJ, Shuk E, Arniella G, Hay LJ. Genetic testing awareness and attitudes among Latinos: Exploring shared perceptions and gender-based differences. Public Health Genomics. 2016; 19(1):34-46.

25. Kaakinen JR, Coehlo DP, Steele R, Robinson M. Family health care nursing: Theory, practice, and research. $6^{\text {th }}$ ed. USA: F.A. Davis; 2018. 213-29.

26. Ahmed HI, Elsayied AE, Girgis N. Primary prevention of genetic disorders among secondary school students in a Rural Area. Journal of
American Science. 2012; 8(6): 63039.

27. Haga SB, Barry WT, Ginsburg GS. Public knowledge of and attitudes toward genetics and genetic testing. genetic testing and molecular biomarkers. 2013;17 (4):327-333.

28. Riesgraf RJ, Le Roy BS, MacFarlane IM, Veach PM. Perceptions and attitudes about genetic counseling among residents of a Midwestern Rural Area. J Genet Counsel. 2015; 24(1):565-579.

29. Al-Farsi OA, Al-Farsi YM, Gupta I, A study on knowledge, attitude, and practice towards premarital carrier screening among adults attending primary healthcare centers in a region in Oman. BMC Public Health. 2014; 14(380)1-7.

30. Al- Haddad AM. Knowledge and attitude about pre-marital counseling among Hadhramout University Students. Zagazig Nursing Journal. 2010; 6(11): 46-65.

31. Maio M, Carrion P, Yaremco E, Austin JC. Awareness of genetic counseling and perceptions of its purpose: A survey of the Canadian public. J Genet Couns. 2013; 22(6): 762-70. 